\title{
Windthrow damage in Picea abies is associated with physical and chemical stem wood properties
}

\author{
Fabian Daniel Meyer · Jens Paulsen • \\ Christian Körner
}

Received: 3 March 2004/Revised: 13 September 2007/Accepted: 29 November 2007/Published online: 10 January 2008 (C) Springer-Verlag 2008

\begin{abstract}
On 26 December 1999, the windstorm "Lothar" hit large parts of western and central Europe. In Switzerland, windthrow losses reached $12.7 \mathrm{Mio} \mathrm{m}^{3}$ of timber, corresponding to 2.8 times the annual national timber harvest. Although these exceptional losses were due to extreme peak velocities, recent changes in tree nutrition may have increased forest susceptibility. Previous controlled environment experiments revealed that wood density (associated with wood stiffness) tends to increase in elevated $\mathrm{CO}_{2}$, and to decrease when $\mathrm{N}$-availability is enhanced (e.g., by soluble N-deposition). Such changes in wood quality could theoretically influence the risk of wind damage. We used the "Lothar" windstorm as a "natural experiment" to explore links between damage and wood properties. In 104 windthrow sites across the Swiss Plateau, more than 1,600 wood cores from (1) broken, (2) uprooted and (3) still standing (not damaged) spruce trees (Picea abies) were collected in February and March 2000. Wood properties, treering width and chemistry of the wood samples were analysed. Broken trees showed wider treerings in the decade 1990-99 compared to non-broken trees (either uprooted or undamaged trees). Broken trees also showed lower non-structural carbohydrate (NSC) concentration in sapwood, reflecting active structural carbohydrate sinks associated with fast growth. There was also a trend for higher tissue $\mathrm{N}$-concentrations in broken trees. No
\end{abstract}

Communicated by T. Speck.

F. D. Meyer · J. Paulsen · C. Körner ( $\varangle)$

Institute of Botany, University of Basel, Schönbeinstrasse 6, 4056 Basel, Switzerland

e-mail: ch.koerner@unibas.ch significant differences between damage types were found in wood density and wood shrinkage during desiccation. We conclude that stem breakage risk of $P$. abies is associated with a stimulation of growth in the past decade and with changes in tree nutritional status. However, the risk for windthrow of whole spruce trees (uprooted but not broken) was not related to the studied wood parameters.

Keywords Forest - Stem fracture - Mechanics . Treerings · Dendrology $\cdot$ Nutrients $\cdot$ Carbohydrates · Spruce $\cdot$ Switzerland

\section{Introduction}

Extreme events in a silviculture landscape

Stochastic disturbance events such as fire or wind damage drive forest dynamics and regeneration. It is well known that tree species differ in their sensitivity to such disturbances and natural regional species abundance is strongly influenced by the recurrence rate of such events. Natural forest systems pass through successional cycles often driven by such disturbances. In contrast, silviculture commonly does not select for these resistance traits if the recurrence rates of such "disasters" is low relative to forest rotation and/or if there are possibilities to prevent or reduce damage by adopting certain management strategies (e.g., fire fighting). Windthrow damage has increased in recent decades (Bresh et al. 2000), although meteorological statistics are not suggesting that storm frequency per se did increase over the past 100 years (Schiesser et al. 1997; OcCC 2003), yet climatic warming may rise the risk of weather extremes such as extratropical cyclones in the near future (Berz 2003). 
Here, we explore whether there is intra-population diversity in windstorm resistance of trees and, if so, what the underlying mechanisms might be. Intraspecific differentiation of risk-traits could-in the long run-select for more resistance, with "survivors" either serving as seed trees or becoming a selected seed source for nurseries. Following a recent centennial storm in the Swiss plateau, we investigated the damage types in windthrow areas in Picea abies (Norway spruce), the dominant conifer timber in central Europe. This assessment is based on the analysis of a large number of tree stems from over 100 locations which were either damaged or which survived in immediate proximity.

There is a suite of conditions, which can contribute to an enhanced risk of windthrow damage. Some of these are obvious others are subtler. Clearly, the windthrow risk is greater for isolated or forest edge positions of trees, and for weak trees grown in the shade of dominant neighbours (Holbrook and Putz 1989). Tree crown asymmetry and size (Amarasekara and Denne 2002; Young and Perkocha 1994), the shape (taper) of a tree (Moore 2000; Wang et al. 1998, Petty and Swain 1985), tree senescence (Zobel and Buijtenen 1989), stem or root rot pathogen infection (Schmid-Haas and Bachofen 1991), rooting on very shallow soil (Moore 2000; Puhe 2003), acidification induced shallow rooting (Puhe 2003), low base saturation in the soil (Braun et al. 2003), or uniform coniferous forest stands (Mason 2002; Schmid-Haas and Bachofen 1991) all enhance the risk of windthrow. Here, we will explore less obvious traits such as the physical and chemical properties of dominant or co-dominant individuals in closed, fairly even aged stands, approaching the end of the common 100 year forest rotation cycle. The natural life expectancy of $P$. abies would be up to 350 years.

We employ soil data (e.g., pH) as well as results of a spatially explicit $\mathrm{N}$-deposition model for the test area (Rihm 1996) for site characterisation. For wood tissue we document mineral element and nitrogen concentrations (e.g., enhanced $\mathrm{N}$-availability or depletion of other nutrients) and non structural carbohydrates (C-supply status) in stem tissue. We will use these signals as indicators of any shift in tree nutrition. In this context we assume that a comparatively high abundance of non-structural carbon compounds (NSC) indicates a situation of carbon surplus perhaps as a result of atmospheric $\mathrm{CO}_{2}$-enrichment or because of non-carbon-associated growth limitations (Hoch et al. 2002; Körner 2003). Similarly, we assume high $\mathrm{N}$-concentrations to indicate appropriate or overabundant $\mathrm{N}$-supply. Since high $\mathrm{N}$-concentrations may result from high N-deposition (Bauer et al. 2000) rather than generally improved nutrient status, ratios between $\mathrm{N}$ and other nutrients such as phosphate or certain cations will be considered as well.
Stem and wood characteristics and the risk of wind damage

This study rests on the assumption that-beyond many other risk factors and irrespective of the environmental triggers which may have led to these characteristics-the likelihood of an adult tree in a given population to become damaged by strong winds is also linked to its wood tissue properties (density) and stem biometrics (Putz et al. 1983). Hence, we ask the simple question whether there are any correlations between damage type and stem wood characteristics in spruce.

A dominant tree, grown under a selective thinning regime (selection stands) is more likely to exhibit a robust stem than a tree grown in a clear-cutting regime without thinning. Accordingly, Dvorak et al. (2001) found lower windstorm damage in Swiss selection stands compared to stands, which regenerated from a clear-cutting regime without thinning. Whatever its cause, the vigour of growth per se can have an integrative effect on the risk of wind damage by a combination of associated stem shape factors, crown size, the width of growth rings and their quality. But it is not clear whether good growth conditions enhance or reduce the risk. To find this out was one of the aims of this study.

Faster growth can have many reasons such as high light (low competition), rich substrate (potentially enhanced by atmospheric nitrogen deposition) or even atmospheric $\mathrm{CO}_{2}$ enrichment. Enhanced N-deposition is assumed to have stimulated forest growth since the 1960s in many parts of Central Europe, but not in Scandinavia, where N-deposition is much lower (Spiecker et al. 1996). In eastern NorthAmerica, N-deposition was not found to have increased N-availability (McLauchlan et al. 2007) possibly due to late consequences of earlier land use and N-depletion and it hardly feeds into forest biomass accumulation (Nadelhoffer et al. 1999). For central Europe, it was, however, argued that many forest sites were $\mathrm{N}$-depleted during the nineteenth and early twentieth century (Kenk and Fischer 1988; Zöttl 1990), which should enhance their sensitivity to current $\mathrm{N}$ deposition. In the early 1990s, the so-called critical load of atmospheric $\mathrm{N}$ deposition was exceeded in 80-99\% of the managed forest area of Switzerland (Rihm 1996).

In situ nitrogen fertilisation almost always stimulates radial wood increment (Joos 1997; Anttonen et al. 2002; Mäkinen et al. 2002) and tree height growth in conifer forests (Alcubilla et al. 1976). Fast-growing versus slowgrowing old spruce trees (high vs. low growth rate) not only differ in ring width, but also in wood density and mean tracheid length (Herman et al. 1998). For wood quality (and presumably wood mechanics), it seems to make a difference if growth is primarily stimulated by 
nitrogen (less stiff wood) or elevated $\mathrm{CO}_{2}$ (stiffer wood). Long-term full nutrient fertiliser addition in $P$. abies leads to wider earlywood, and reduced wood density and latewood fraction (Mäkinen et al. 2002). Mean wood density may be used as a proxy for the contribution of the latewood fraction to the complete treering, because latewood has much higher density than earlywood (Wimmer 1995).

Spruce grown under $\mathrm{N} \times \mathrm{CO}_{2}$-enrichment with two different soil types (an acidic, silty and a calcareous, sandy soil) produced less rigid wood when receiving more nutrients on acidic soil, but not on the naturally more fertile calcareous soil (Beismann et al. 2002). The soil type itself influenced elasticity and density of wood, independently of the $\mathrm{CO}_{2}$ and $\mathrm{N}$-treatment (neither $\mathrm{CO}_{2}$ nor $\mathrm{N}$-enrichment showed any effect on wood density). On the less fertile acidic soil, density, rigidity and toughness of wood were generally higher (Beismann et al. 2002). Applied together, $\mathrm{CO}_{2}$-effects may even become compensated by the opposing effects of high $\mathrm{N}$ deposition.

In addition to wood structure, wood chemistry can also be affected by $\mathrm{CO}_{2}$-enrichment and $\mathrm{N}$ addition. In a 3-year experiment with stands of $P$. abies saplings growing on mature forest soil in fully air conditioned chambers, elevated $\mathrm{CO}_{2}$ led to higher starch concentration and lignin/ $\mathrm{N}$ ratio and reduced $\mathrm{N}$ concentration (Hättenschwiler et al. 1996), whereas $\mathrm{N}$-addition alone or in combination with $\mathrm{CO}_{2}$-enrichment had no effect on starch, $\mathrm{N}$ and lignin concentration in branch wood in these model ecosystems. In an 11 year nitrogen fertilisation trial with $P$. abies (Anttonen et al. 2002), lignin, soluble sugars and other extractives became increased compared to controls.

\section{The storm Lothar as a test case}

We designed this field study to test some of these earlier experimental findings and the theory discussed above in adult trees after a winter-storm had hit large parts of central Europe on 26 December 1999, with peak velocities of $160 \mathrm{~km} \mathrm{~h}^{-1}$ and $12.7 \mathrm{Mio}^{3}$ of fallen timber in Switzerland (about 2.8 times the annual Swiss timber harvest; WSL/BUWAL 1999). We selected 104 sites with wind damage in previously dense forests of similar age. In the damaged areas, we selected a set of trunks, which were either uprooted, or broken and collected the same data from adjacent, now isolated individuals, which for whatever reason resisted the storm.

In the light of the above discussion, we hypothesized (1) that trees with broken stems should have softer i.e., less dense wood, higher nitrogen concentrations in xylem and phloem and lower concentrations of non-structural carbohydrates than undamaged or even uprooted trees. We thus, assume that a high nutrient supply allows structural sinks to be very active; so that the tree can invest most carbon assimilates into new structural tissue. In contrast we expected (2) uprooted trees to have stiffer stems, which transmit the mechanical forcing by the storm on crowns more directly to the root plate. We assume the greater stiffness to be associated with greater wood density, which in turn reflects smaller ring width, all, tied to a higher carbon and lower $\mathrm{N}$-supply (superfluous carbon being stored as non-structural carbon).

Our findings may be associated with a multitude of influences other than the $\mathrm{C} / \mathrm{N}$-balance, but we expected that a very large sample of trees and a very broad representation of sites over as large as possible an area should provide sufficient statistical power to identify the hypothesized trends, should the predicted functional links exist. It was imperative for this broad survey to use simple to determine parameters, which permitted the sampling campaign to be completed during a few weeks of cold winter weather immediately after the storm, not at risk to lose signals by the onset of decay during warmer weather.

\section{Methods}

Sites and sampling procedure

Picea abies L., our test-species dominated all sites ( $57 \pm 21 \%$ of all trees; mean \pm SD) followed by Abies alba $(15 \pm 19 \%)$ and Fagus sylvatica (13\%). Species of minor importance were Pinus sylvestris, Larix decidua, Quercus spp. and Acer spp. Less than a quarter of the sites were pure coniferous forests ( $>95 \%$ conifer cover). The mean canopy height for all 104 sites was ca $32 \pm 5$ (SD) $\mathrm{m}$. The 104 locations selected, cover a broad spectrum of windthrow sites spread over an area of ca. 10,000 km across the Swiss Plateau (a quarter of Switzerland) and across altitudes between 295 and $1,450 \mathrm{~m}$ (mean $603 \pm 200$ (SD) m a.s.l.; Fig. 1). We aimed at sampling ca five trees of each category of (1) broken B, (2) uprooted U and (3) undamaged, "control" trees $\mathrm{C}$ at each site (i.e., 15 trees per site). However, in one case we found no broken trees, and in nine cases we found no uprooted trees. In all other cases, we could sample 2-14 trees per damage category, mostly six trees. In order to avoid forest edge effects, the wind throw plots used were surrounded by forest, with an intact-forested buffer zone to the west (the wind direction) of mostly more than $50 \mathrm{~m}$ width. In addition, the sampling sites were selected to match the following criteria: (1) The terrain should be flat, with gentle surrounding topography (no steep slopes, narrow valleys). (2) The original forest should be closed and mature. (3) All threedamage types should be well represented. The mean site area was around 5 ha (min. 0.5 , max. 50 ha). 


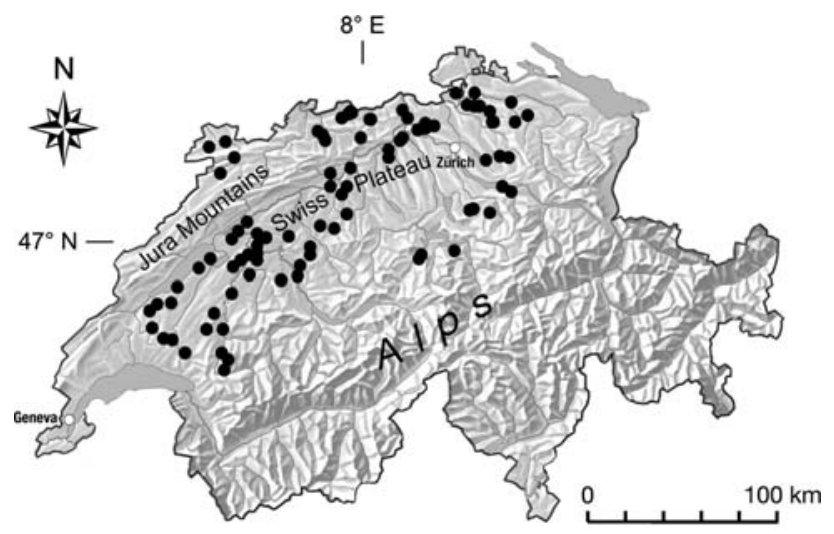

Fig. 1 Location of sampling sites $(n=104)$ on the Swiss Plateau

We estimated stand height, tree species composition (the fraction contributed by spruce in cases where other species were present), estimated the fractions of undamaged, broken and uprooted trees. We also recorded altitude above see level, slope orientation, slope inclination and soil type. During sampling in February and early March 2000, the weather conditions were cold $\left(+2\right.$ to $-1{ }^{\circ} \mathrm{C}$, mostly around zero) and wet, with slight snow cover in many of the sites, hence wood conditions should be well preserved since the damage on December 26.

\section{Soil analyses}

For each site, three soil samples of ca. $500 \mathrm{~g}$ were taken from the A-horizon (ca. 5-10 cm depth) and were pooled for analyses. Soil samples were stored at $-20^{\circ} \mathrm{C}$ for 4 6 months until analysis. The $\mathrm{pH}$ was measured using electrode sensors in a soil suspension with $1 \mathrm{~m} \mathrm{KCl}$. We analysed soils for $\mathrm{NH}_{4}{ }^{+}$using a colorimetric kit (Merck Spectroquant Ammonium test kit, Merck KGaA, Darmstadt, Germany).

\section{Nitrogen deposition data}

Nitrogen deposition data were obtained from Rihm (1996), who modelled wet and soluble dry $\mathrm{N}$-input for any $1 \times 1 \mathrm{~km}$ grid point in Switzerland. The grid point nearest to each sampling site of the present study was used as an estimate of the mean deposition rate for the period 19931998 (kg N ha ${ }^{-1} \mathrm{a}^{-1}$; Fig. 2).

\section{Tree data}

When we collected stem cores (see below), we also measured the stem diameter at $1.3 \mathrm{~m}$ above ground $(\mathrm{DBH}, \mathrm{m})$,

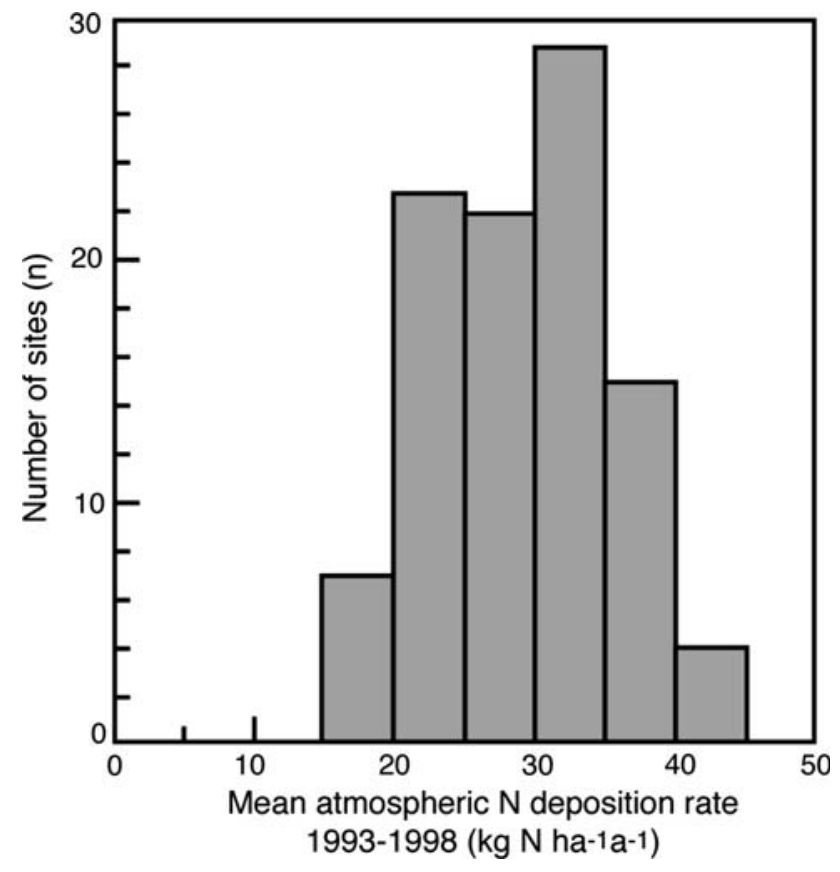

Fig. 2 Frequency distribution of the mean annual atmospheric nitrogen deposition for the 104 sampling sites as shown in Fig. 1 for the period 1993-1998. The data were kindly provided by B. Rihm, Meteotest, Bern. The critical load ranges between 20 and $30 \mathrm{~kg} \mathrm{~N}$ $\mathrm{ha}^{-1} \mathrm{a}^{-1}$ depending on topography, altitude and soil type and is exceeded in more than about $40 \%$ of all the investigated sites. Deposition rates are derived from the $1 \times 1 \mathrm{~km}$ grid Swiss $\mathrm{N}$ deposition map (Rihm 1996)

the distance from lowest to the uppermost point of the irregular shaped stem fracture (stem fracture length), and the distance from soil surface to the lowest point of the stem fracture (stem fracture height).

We collected one core from each tree (a total of 1,835 cores). Trees for which cores showed signs of fungal infestation (wood rot) were excluded from the analysis, reducing the sample to a total of 1,716 wood cores (6-28 per site, with an average of 17). At each site, cores were sampled from trees belonging to the three damage categories $\mathrm{C}, \mathrm{B}$ and $\mathrm{U}$ as described above. The cores were taken $1.3 \mathrm{~m}$ above the base of trees using $5 \mathrm{~mm}$ diameter increment borer (Suunto Inc, Vantaa, Finland). Cores were stored in a cooling box and transferred to a freezer $\left(-20^{\circ} \mathrm{C}\right)$ within $72 \mathrm{~h}$ and maintained there until further analysis.

Sapwood width was determined by inspecting fresh cores. In spruce the sapwood-hardwood boundary can only be detected in fresh wood. The sapwood area was calculated using the diameter at breast height of the tree and sapwood width. The percent (\%) of sapwood area was calculated for each tree, with total basal area representing $100 \%$.

Core handling: At first, the bark (dead part) was removed from each core and a ca. $1 \mathrm{~mm}$ slice of life 
phloem attached to the cambium was cut from the core (Fig. 3). The length of the xylem core was then reduced at the pithward end to a constant length of $65 \mathrm{~mm}$ for all cores. For these $65 \mathrm{~mm}$ xylem cores, the diameter and weight (fresh and oven dried at $80^{\circ} \mathrm{C}$ ) were determined and the basic density calculated. Radial shrinkage of cores due to drying was calculated as the length reduction of the cores after drying at $80^{\circ} \mathrm{C}$. Cores were then split along the radial tree alignment into two equal halves. One half was used for microscopic treering analysis and the second half was used for chemical analysis. Cores were stored over silica-gel in a refrigerator.

\section{Treering analysis}

Treering width was measured in sanded cores to $0.01 \mathrm{~mm}$ with a computerized measuring table ("LINTAB3" with TSAP software version 3.1, Rinntech.com, Heidelberg, Germany; Rinn, 1996). Around 1,169 cores (from a total of 1,716) were suitable for treering measurements. Tree age, defined as cambial age, is the age in the year when the last treering was formed at a given coring height (Bräker 1981; Norton et al. 1987; McCarthy et al. 1991). Since only the outer $65 \mathrm{~mm}$ were available, we could only produce a coarse approximation of age by dividing the intact tree radius by the mean treering width in the $65 \mathrm{~mm}$ core. The absolute tree age is higher by the number of years it took the tree (pith) to reach coring height of $1.3 \mathrm{~m} \mathrm{(10-}$ 30 years).

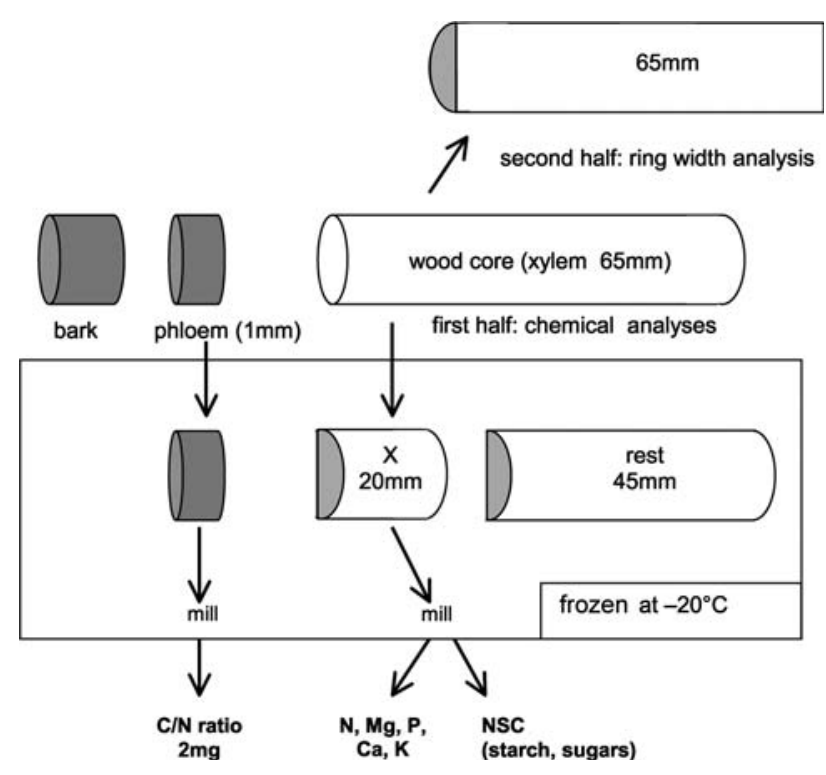

Fig. 3 Processing scheme of the wood samples

\section{Wood chemistry}

The outermost $20 \mathrm{~mm}$ of the core's half was saved for chemical analysis (Fig. 3) and ground to fine powder in a ball mill (MM2, Retsch GmbH \& Co. KG, Haan, Germany). This part of the core contains only sapwood (living xylem). In order to avoid pseudo-replication, all trees of the same damage type were pooled per site, yielding one control (C), one broken (B) and one uprooted (U) sample per site. Each of these site specific means is based, on average, on 8.5, 5.7 and 2.6 trees for control, broken and uprooted trees. Nitrogen concentration was analysed in both sapwood and the phloem segment for each site (102 sites) and all three damage types. Phloem nitrogen concentrations were analysed with a $\mathrm{CHN}$ analyser (CHN900, LECO Corp. St Joseph, MI, USA). Xylem nitrogen concentrations were too low for the $\mathrm{CHN}$ analyser; hence we had to employ a modified micro-Kjehldahl method (Walinga et al. 1995). The method for NSC analysis (starch, glucose, fructose and sucrose) was described in detail by Körner and Miglietta (1994). In essence, this method involves enzymatic digests and a photometric glucose test using a Hexokinase reaction kit (Sigma Diagnostics St Louis, MO, USA). For further site characterisation, the concentration of $\mathrm{Mg}, \mathrm{P}, \mathrm{K}$ and $\mathrm{Ca}$ in the xylem of control trees only was analysed with energy dispersive X-ray fluorescence spectrometry (ED-XRF spectrometer Spectrace-5000). About $2 \mathrm{mg}$ of wood powder was dispersed on clean transparent sticky tape used for taking fingerprints ("police tape"), mounted on a Plexiglas frame. The scanning time for each sample was 500 s. For calibration we used three standards of plant tissue powder certified and provided by the European bureau of calibration (Anonymous 1986). One reference was composed of the aquatic plant Lagarosiphon major (BCR-60), one was composed of the aquatic moss Platihypnidium riparioides (BCR-61), and one was composed of the leaves of Olea europaea (BCR-62).

\section{Statistical analyses}

The differences between the damage types control (C), broken (B) and uprooted (U) were tested with a one-way analysis of variance (ANOVA) and post-hoc $t$ tests with SIDAK's adjustments for multiple comparisons (SPSS Inc. 2000). Where needed, data were transformed to meet the requirements of normal distribution. Multiple $t$ tests were used to analyse differences between the following two test pairs: damaged trees ( $\mathrm{B}$ and $\mathrm{U}$ trees pooled) compared to not damaged trees (i.e., control trees), and the comparison "broken" (B) with not broken trees (U and C trees pooled). In addition, we tested correlations between site, tree and 
wood core data. First of all, rank order correlations were applied because of deviation of the data distribution from normality. The influence of dependent ("masking") factors was reduced by calculating partial correlation coefficients.

\section{Results}

Soils

The majority of the soils was rather acid. The $\mathrm{pH}$ (in $\mathrm{KCl}$ ) with a mean of $3.9 \pm 1.4$ for 100 sites ranged from 2.4 to $7.3 \mathrm{pH}$ values did not correlate with $\mathrm{N}$-deposition rates derived from the N-deposition model by Rihm (1996). The critical load of $20-30 \mathrm{~kg} \mathrm{~N} \mathrm{ha}^{-1} \mathrm{a}^{-1}$ is exceeded in most of our sampling sites (Fig. 2). The concentration of ammonium nitrogen (mean of $395 \pm 55 \mu \mathrm{g} \mathrm{NH} \mathrm{NH}_{4}-\mathrm{N} \mathrm{g}^{-1}$ d.m. of soil) revealed no informative correlation with any tree or other site characteristics, hence is not further discussed. Control trees exhibit $\mathrm{P}$ and $\mathrm{Mg}$ concentrations in the xylem are within the range of the cited studies (Table 1), whereas $\mathrm{Ca}$ concentrations are low, and $\mathrm{K}$ concentrations are particularly low compared to these references. No regional trends could be detected.

Tree damage and tree dimensions

Stem diameter at $1.3 \mathrm{~m}$ height above soil $(\mathrm{DBH})$ and tree age did not differ significantly among different damage types (not shown). For the ca. 1,800 trees measured, the average DBH was $45 \pm 12$ (SD) $\mathrm{cm}$, tree age (cambial age at $1.3 \mathrm{~m}$ ) was $129 \pm 51(\mathrm{SD})$ years, ranging from 24 to 248 years. The mean slenderness ratio was $76 \pm 18$ (SD) $\mathrm{m}$ height per meter of tree diameter with a minimum of 47 and a maximum of 155 . In broken trees, mean fracture height was $5.6 \pm 2.8(\mathrm{SD}) \mathrm{m}$ above ground and the length of the fracture was $0.54 \pm 0.43(\mathrm{SD}) \mathrm{m}$. Neither sapwood width nor sapwood area differed significantly between different damage types. However, the fraction of sapwood area in relation to tree basal area was significantly higher in $\mathrm{B}$ than in $\mathrm{C}+\mathrm{U}$ trees (Fig. 4). Although not significant $(p=0.19)$, the sapwood fraction was also slightly higher in $\mathrm{B}$ trees than in either $\mathrm{C}$ or $\mathrm{U}$ trees tested separately.

\section{Treering analysis}

The mean treering width of the 1,169 measured $65 \mathrm{~mm}$ wood cores was $1.88 \pm 0.57 \mathrm{~mm}$ and $37 \pm 10$ treerings were found within the considered $65 \mathrm{~mm}$-wood cores (on average, the years 1962-1999). Over the last 10 years (1990-1999), mean treering width was $1.96 \pm 0.61 \mathrm{~mm}$, which is marginally higher than that for the whole $65 \mathrm{~mm}$ cores. Note that the product of the mean ring width and the mean number of years per core is not equal to $65 \mathrm{~mm}$ because the results differ when the number of years and mean ring width are averaged first, instead of multiplying original values first and averaging them thereafter. These annual radial increments in the $65 \mathrm{~mm}$-wood cores correspond to a mean annual basal area increment of $24.5 \pm 7.1 \mathrm{~cm}^{2}$ per tree $\left(25.6 \pm 7.9 \mathrm{~cm}^{2}\right.$ for $1990-1999$ only).

Damaged trees $(\mathrm{B}+\mathrm{U})$ showed significantly higher $(+3.5 \%)$ mean treering width in the $65 \mathrm{~mm}$ cores than undamaged (C) trees $(p<0.05)$ with the uprooted trees contributing more to this difference $(+4.9 \%$; not significant for $\mathrm{U}$ alone) than the broken trees $(+2.1 \%$, n.s. for B alone; Fig. 5). However, if we consider the last 10 years only, this trend becomes reverted, and broken trees show

Table 1 Element concentrations in sapwood of control trees (means and standard deviations; $\mathrm{mg} \mathrm{g}^{-1}$ of dry matter), compared with literature values

\begin{tabular}{|c|c|c|c|c|c|c|c|}
\hline Sapwood content ( $\mathrm{mg} \mathrm{g}^{-1}$ d.m.) & Sapwood section $(\mathrm{cm})$ & $\mathrm{N}$ & $\mathrm{P}$ & $\mathrm{N} / \mathrm{P}$ & $\mathrm{Mg}$ & $\mathrm{Ca}$ & $\mathrm{K}$ \\
\hline Present study (control trees) & $0-2$ & $0.87 \pm 0.01$ & $0.049 \pm 0.002$ & $17.5^{\mathrm{a}}$ & 0.11 & 0.34 & $0.06 \pm 0.002$ \\
\hline Stockfors and Linder (1998); control & $0-2.5(-3.5)$ & $0.69 \pm 0.07$ & - & - & - & - & - \\
\hline Stockfors and Linder (1998); fertilized & $0-2.5(-3.5)$ & $0.79 \pm 0.06$ & - & - & - & - & - \\
\hline Braun et al. $(1996)^{\mathrm{b}}$ & $0-5$ & $0.61 \pm 0.06$ & $0.033 \pm 0.08$ & 18.5 & 0.11 & 0.83 & 0.85 \\
\hline Feger et al. (1991) & - & 0.30 & 0.02 & 15.0 & 0.09 & 0.50 & 0.30 \\
\hline Dünisch et al. (1996) (healthy trees) ${ }^{\mathrm{c}}$ & - & - & $0.06 \pm 0.38$ & - & $0.08 \pm 0.24$ & $0.60 \pm 0.85$ & $0.36 \pm 1.07$ \\
\hline Joos (1997) (non-fertilized trees) & $0-1.5$ & - & $0.05 \pm 0.20$ & - & $0.05 \pm 0.13$ & $0.45 \pm 0.70$ & $0.20 \pm 0.90$ \\
\hline
\end{tabular}

For further explanation see text

${ }^{a} \mathrm{~N} / \mathrm{P}$ ratio is $20.4 \pm 0.8$, when the $\mathrm{N} / \mathrm{P}$ ratio is first calculated for any site, and averaged thereafter

b Seven sites ("Urnerland") were included; P concentration in needles is a mean of four sites

c Values depend upon distance from bark; complete sapwood was measured in healthy trees only 


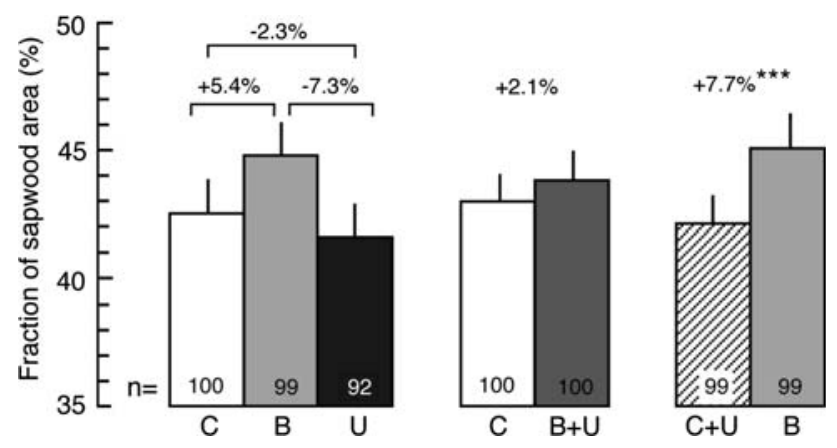

Fig. 4 Differences in the percentage of sapwood area among the three damage types: control (C), broken (B) and uprooted (U). Asterisks mark the significance level: $* * * p<0.001$. Error bars represent standard errors. The pairwise differences between the damage types are given as a \% difference. The $\mathrm{C}$ and $\mathrm{C}+\mathrm{U}$ values respectively are taken as $100 \%$

marginally significant $(p=0.067)$ wider treerings $(+5.7 \%)$ than all the unbroken trees $(\mathrm{C}+\mathrm{U})$, with absolutely no $\mathrm{C}$ versus $\mathrm{U}$ difference, hence the damaged $(\mathrm{B}+\mathrm{U})$ versus control difference becomes insignificant.

Physical wood tissue characteristics

Across all trees, the mean fresh (moist) wood density was $0.705 \pm 0.059 \mathrm{~g} \mathrm{~cm}^{-3}$ (mean \pm standard deviation) and the oven-dry wood density was $0.369 \pm 0.023 \mathrm{~g} \mathrm{~cm}^{-3}$. The $65 \mathrm{~mm}$-cores showed a mean radial shrinkage due to drying (sample length reduction) of $3.9 \pm 0.4 \%$. Sapwood area across all tree categories contributed $43 \pm 12 \%$ to tree basal area at coring height (total basal area is 100\%).

Fresh wood density is significantly higher in B trees than in either $\mathrm{U}$ or $\mathrm{C}$ trees (Fig. 5). Fresh wood density is also significantly greater for all damaged $(\mathrm{B}+\mathrm{U})$ trees together $(+3.7 \%)$ than in control trees and in B only versus all nonbroken $(\mathrm{C}+\mathrm{U})$. Although not significant, the differences in oven-dry density between damage types show similar trends when the damage types are considered separately (Fig. 5). It should be recalled that fresh wood density is higher the more water (density $=1$ ) is contained in the wood samples. However, structural characteristics (e.g., lignification) and solutes can also add to fresh density. In essence, there is a clear trend for higher fresh density $(\sim$ water content $)$ in broken trees. Density differences disappear when wood is dry. No significant differences between damage types were found in radial shrinkage.

\section{Wood chemistry}

Across all trees, the mean concentration of non-structural carbohydrates (NSC) in the sapwood $(20 \mathrm{~mm})$ was $1.21 \pm 0.23 \%$ (mean $\pm \mathrm{SD}$ ) of dry matter (d.m.), of which
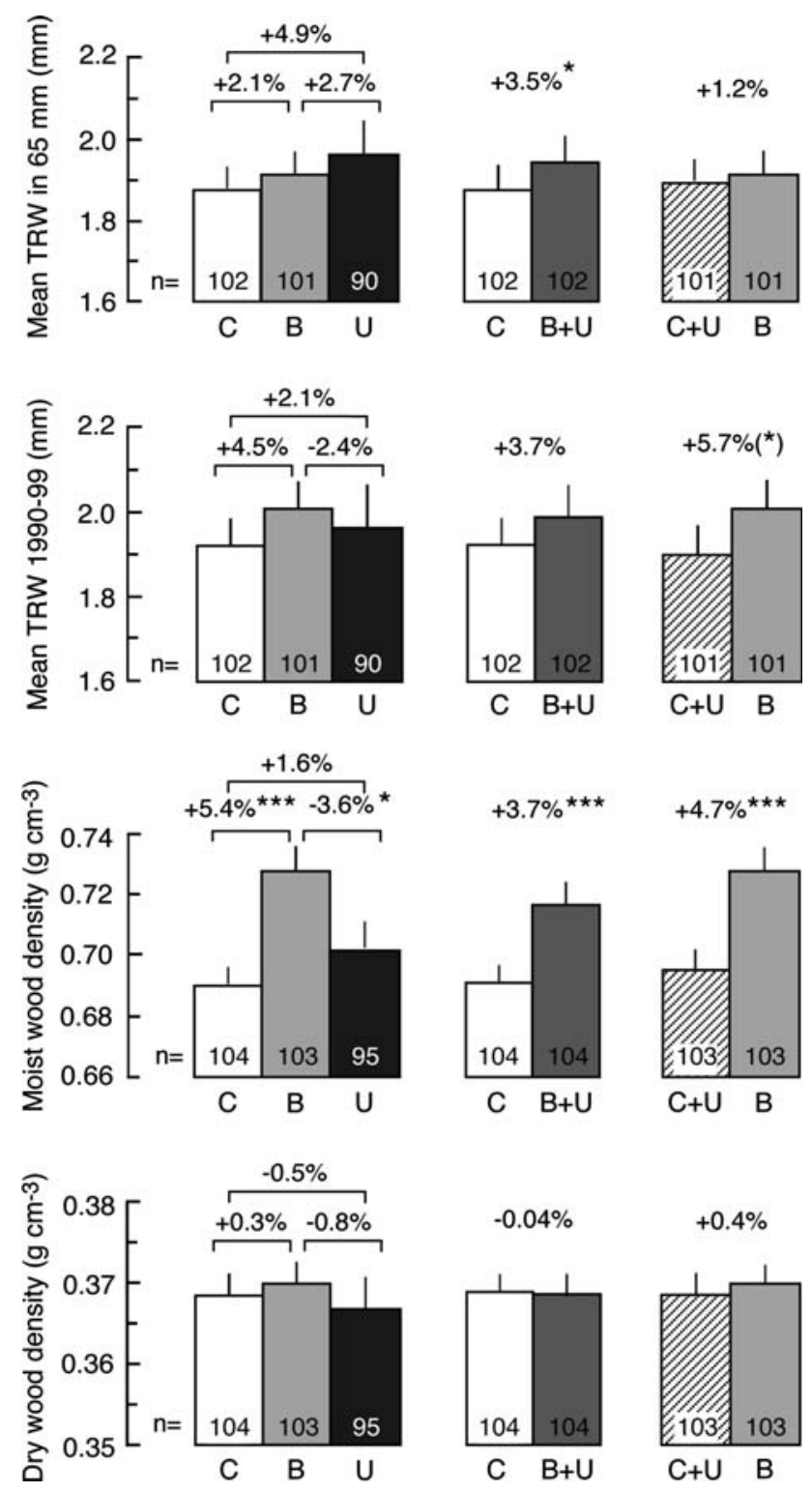

Fig. 5 Differences in treering width (TRW) and wood density between pairs of the three damage types: control (C), broken (B) and uprooted (U). Asterisks mark the significance level: $* * * p<0.001 ; * * p<0.01$; * $p<0.05$; (asterisk) $p<0.1$. For further explanation see Fig. 4

starch contributed $0.67 \pm 0.17 \%$ d.m. and sugars contributed $0.54 \pm 0.21 \% \quad$ d.m. (mean $\pm \mathrm{SD}$ ). The NSC concentration in sapwood of broken trees is significantly lower $(-11 \%)$ than in all un-broken $(\mathrm{C}+\mathrm{U})$ trees, and $14 \%$ lower than in uprooted trees alone, while broken versus control trees alone do not differ significantly (Fig. 6). Wood of damaged trees combined $(\mathrm{B}+\mathrm{U})$ contains significantly less starch than controls (Fig. 6).

Mean $\mathrm{N}$ concentration in the sapwood of control trees was $0.087 \pm 0.01 \%$ d.m., and the $\mathrm{N}$ concentration in the phloem was $0.35 \pm 0.06 \%$ d.m. Sapwood samples represent $14 \pm 4(\mathrm{SD})$ treerings within the $20 \mathrm{~mm}$-section 

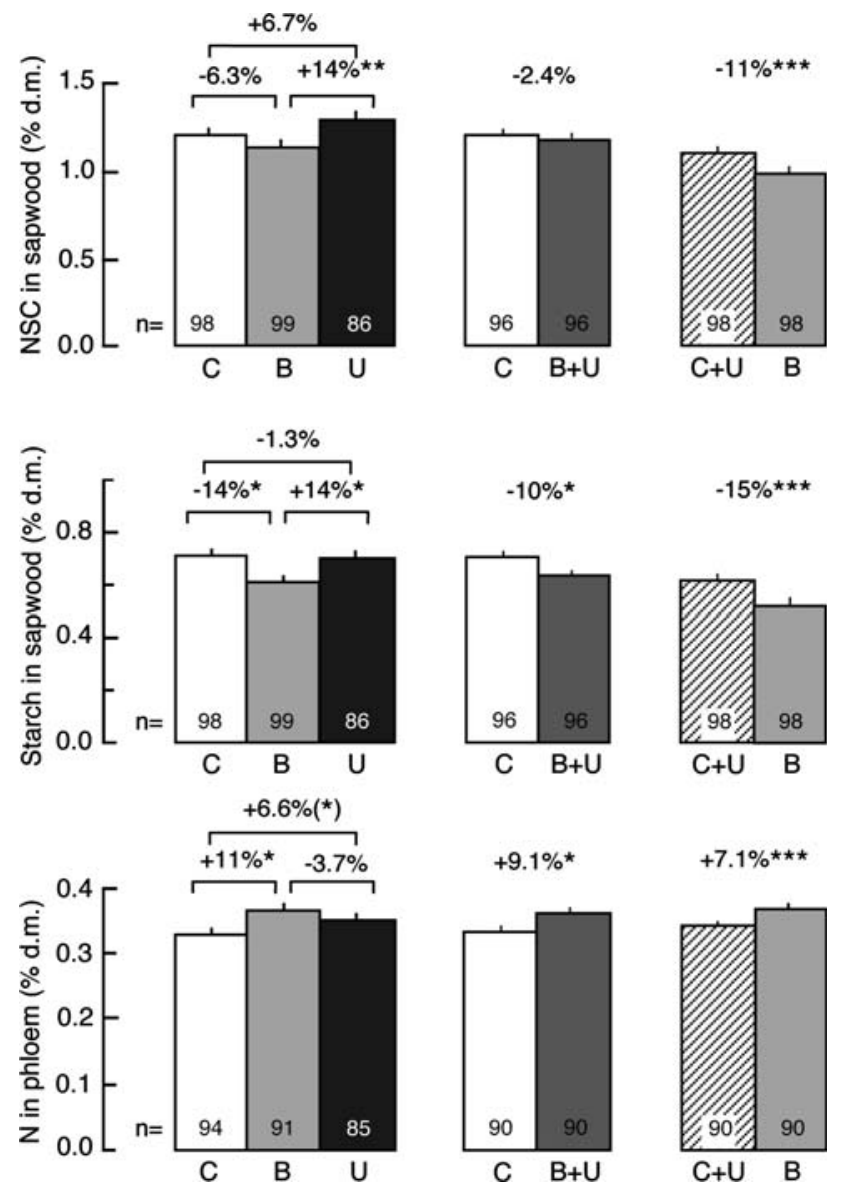

Fig. 6 Differences in non-structural carbohydrates (NSC), starch in sapwood, and $\mathrm{N}$ in stem phloem. For further explanation see Fig. 5

examined (the years 1985-1999). In comparison with four other studies (Table 1), these $\mathrm{N}$-concentrations in wood are high. Separated by damage type, N-concentration shows trends opposing those in NSC-concentration. There is a trend of higher $\mathrm{N}$ concentrations in sapwood of damaged trees compared to undamaged trees $(=$ control), but the absolute difference is quite small (n.s.). Differences in $\mathrm{N}$-concentration in the phloem are more pronounced with much higher concentrations in broken trees than in control trees, and concentrations are also higher in uprooted than in control trees (Fig. 6). Damaged trees $(\mathrm{B}+\mathrm{U})$ pooled also show significantly higher $\mathrm{N}$-concentrations in the phloem than undamaged (C) trees alone, largely because of the strong signal in broken trees. Broken trees also show significantly higher $\mathrm{N}$-concentration in the phloem when compared to all un-broken trees together $(\mathrm{C}+\mathrm{U}$; Fig. 6).

Above, we presented concentrations of wood constituents on a dry matter basis, which makes signals sensitive to changes of cell wall density (e.g., lignin concentration). However, when concentrations are calculated on a tissue volume basis, neither the direction nor the significance of the differences change (data not shown).
In summary, the xylem of broken trees contains more water, thus exhibits higher fresh wood density, and sapwood and phloem show a higher nitrogen concentration per unit dry matter. Broken trees also grew faster than unbroken trees $(\mathrm{C}+\mathrm{U})$ over the last 10 years (1990-1999), which is in line with their lower non-structural carbohydrate concentrations when compared with all un-broken trees $(\mathrm{C}+\mathrm{U}$ pooled). Based on these parameters, broken trees are clearly different from both uprooted (unbroken) and control trees. There were a few marginal differences between $\mathrm{B}$ and $\mathrm{U}$ which made the broken trees even more different when compared with the combined mean of $\mathrm{C}+\mathrm{U}$.

\section{Correlations}

In contrast to controlled experiments, the analysis of "natural experiments" such as the wind throw case studied here, encounters a broad range of uncontrolled co-variables, which may have an influence on the results. On the other hand, this broad range also offers the possibility to explore correlations among many factors and recorded tree responses. Among the ca 40 parameters analysed in this study, hundreds of correlations could be tested, some of which would be significant by chance, and others make no biological sense. We explored large matrices of such correlations and will present and discuss only a few which we think do contribute to the understanding of the phenomena presented. Many of the tested parameters did not show a perfect Gaussian distribution. Thus, for all the possible tests, both Spearman's rank sum correlation and the common Pearson's correlation coefficients were calculated. As to be expected, we also found a high collinearity (Belsley 1990, Chatterjee et al. 2000) between some factors (e.g., canopy height is of course highly correlated with DBH, and DBH is correlated with tree age). Therefore, the collinearity in these factors was reduced by calculating partial correlations. For example, in the correlation between DBH and treering width, tree age and canopy height are "controlling factors", because they control or cover the searched correlation. Controlling factors are sometimes also called "masking factors", because they mask the searched correlations. Although many relationships lose their strength and statistical significance in partial correlations (they even sometimes change their sign), the remaining significant ones are more likely reflecting relevant biological phenomena.

Stem fracture length and stem fracture height are proxy variables for the fracture properties of a tree stem. A short fracture indicates a brittle tree stem, and a long fracture indicates an elastic stem (Seeling 1999). Fracture length increased with radial stem wood shrinkage during desiccation and with higher oven-dry wood density and it decreased with tree slenderness and the size of the sapwood 
Table 2 Partial correlation coefficients between stem fracture length, stem fracture height and selected other variables (number of sites $n=50$ )

\begin{tabular}{lll}
\hline & \multicolumn{2}{l}{ Stem fracture } \\
\cline { 2 - 3 } & Length & Height \\
\hline Radial stem wood shrinkage $(\%)$ & $0.28^{*}$ & n.s. \\
Oven-dry wood density $\left(\mathrm{g} \mathrm{cm}^{-3}\right)$ & $0.37^{* *}$ & n.s. \\
Slenderness (canopy height/tree diameter) & $-0.30^{*}$ & n.s. \\
Fraction of sapwood area $(\%)$ & $-0.29^{*}$ & n.s. \\
N in sapwood of control trees $(\%$ d.m.) & n.s. & $0.42^{* *}$ \\
P in sapwood of control trees $(\%$ d.m.) & n.s. & $0.30^{*}$ \\
K in sapwood of control trees $(\%$ d.m.) & n.s. & $0.27^{*}$ \\
\hline
\end{tabular}

Sapwood length, moist wood density, tree age, DBH, site altitude and date of sampling were used as controlling factors. Statistically significant correlations are presented only $(* p<0.05$; $* * p<0.01$; $* * * p<0.001)$

fraction (Table 2). The degree of radial wood shrinkage during desiccation increases and, surprisingly, treering width decreases with total atmospheric $\mathrm{N}$-deposition (Table 3). It seems, beyond a certain critical N-deposition, or more likely with the associated acidification, effects on growth become negative. We found no significant differences between the different damage types in multiple linear regression models.

\section{Discussion}

Using a geographically broad treering data set, this study revealed that the type of wind-throw damage during the 1999 extreme event was associated wit stem wood properties, which in turn reflected tree vigour and tree nutrition. The results confirm the hypothesized antagonistic role of nitrogen nutrition and tree carbon supply status. Faster growth is associated with high tissue $\mathrm{N}$-concentration and depleted non-structural carbohydrate pools and increases the risk of stem breakage compared to the risk of uprooting. Similar traits in uprooted and undamaged survivors within a windbreak plot, suggest that stem breakage is not a purely random phenomenon, but is associated with a specific set of tree characteristics sensitive to growth conditions.

We found no difference in stem diameter between the damage types $\mathrm{C}-\mathrm{B}-\mathrm{U}$, in line with earlier observations by Schmid-Haas and Bachofen (1991), who also found no effect of height/diameter ratio on wind storm damage in spruce (they also found no effect of crown length). At the peak velocities of Lothar of up to $160 \mathrm{~km} \mathrm{~h}^{-1}$, it seems that trees were hit irrespective of their size, associated with stochastic peak turbulences.

Our findings do not support expectations that the risk of wind-throw of a single tree is related to its size and proportions in the type of forests explored here (Niklas 1992, 1994; Dunham and Cameron 2000). These factors matter for isolated trees or irregular canopies, but possibly not for the remaining crown variance in otherwise even forest canopies. The height to diameter ratio (H/D, slenderness) is a widely used classical risk index (Wang et al. 1998). A tree with a value equal or higher than 100, is highly vulnerable by wind storms. The mean height to diameter ratio of all trees within a site $(\mathrm{C}-\mathrm{B}-\mathrm{U})$ was 76 and 12 of a total of 104 sites showed a height to diameter ratio of above 100 . The fact that $59 \%$ of the stands we investigated showed mean H/D values lower than 80 , and the wide range between 47 and 155 indicates that stands were thrown irrespective of tree slenderness.

\section{Damage type differences}

The most significant difference we observed was between broken and non-broken trees. Broken trees show higher

Table 3 Partial correlation coefficients among physical wood properties as derived from $5 \mathrm{~mm}$ cores

\begin{tabular}{|c|c|c|c|c|c|}
\hline & $\begin{array}{l}\text { Fraction of } \\
\text { sapwood area }(\%)\end{array}$ & $\begin{array}{l}\text { Radial stem } \\
\text { wood shrinkage (\%) }\end{array}$ & $\begin{array}{l}\text { Oven-dry } \\
\text { wood density }\left(\mathrm{g} \mathrm{cm}^{-3}\right)\end{array}$ & $\begin{array}{l}\text { Mean TRW } \\
(\mathrm{mm})\end{array}$ & $\begin{array}{l}\text { Deposition of } \\
\text { all } \mathrm{N} \text { compounds }\end{array}$ \\
\hline $\begin{array}{l}\text { Fraction of sapwood area } \\
\text { (\% of basal area) }\end{array}$ & 1 & & & & \\
\hline $\begin{array}{l}\text { Radial stem wood } \\
\text { shrinkage }(\%)\end{array}$ & $-0.31 * * *$ & 1 & & & \\
\hline $\begin{array}{l}\text { Oven-dry wood } \\
\text { density }\left(\mathrm{g} \mathrm{cm}^{-3}\right)\end{array}$ & $-0.29 * * *$ & $0.69 * * *$ & 1 & & \\
\hline Mean TRW (mm) & $0.30 * * *$ & $-0.44 * * *$ & $-0.49 * * *$ & 1 & \\
\hline $\begin{array}{l}\text { Deposition of all } \\
\mathrm{N} \text { compounds }\end{array}$ & n.s. & $0.28 * *$ & n.s. & $-0.33 * *$ & 1 \\
\hline
\end{tabular}

Controlling factors are sapwood length, moist wood density, tree age, diameter at breast height (DBH), site altitude and date of sampling. Deposition of soluble $\mathrm{N}$ compounds (mean for 1993-1998; $\mathrm{kg} \mathrm{N} \mathrm{ha}^{-1} \mathrm{a}^{-1}$ ). TRW is a mean value of tree-ring width of the outer $65 \mathrm{~mm}$ of stem cores 
fresh wood density (more water), greater fraction of sapwood area, lower non-structural carbohydrate and starch concentrations in the sapwood, and higher nitrogen concentrations in the phloem, all together suggesting more vigorous growth and high structural sink activity for carbon assimilates as evidenced by wider treerings in broken trees over the last 10 years (1990-1999), trends clearly in line with our hypothesis. It is known from open top chamber experiments that spruce grown under enhanced $\mathrm{N}$-supply on acidic forest soil produces wood of reduced bending stiffness, whereas $\mathrm{CO}_{2}$ without $\mathrm{N}$-addition enrichment leads to increased fracture toughness (Beismann et al. 2002). The association of stem breakage with higher $\mathrm{N}$-supply, and the production of wider and softer treerings observed here, lines up with experimental results which documented a reduction in dry wood density in response to $\mathrm{N}$-fertilizer and an increase with $\mathrm{CO}_{2}$-enrichment (Hättenschwiler et al. 1996). Many of our test sites receive excess $\mathrm{N}$-deposition, reflected by an elevated phloem $\mathrm{N}$-concentration that is commonly tightly correlated with leaf N-concentration (Hohenadel et al. 1978). The higher $\mathrm{N}$-concentration found in broken "Lothar" trees most likely reflects higher $\mathrm{N}$-supply of these trees. It remains unclear why and how such differences among groups of trees can develop in a single stand under otherwise common environmental conditions. Such differences (and the associated damage risk) do not seem to relate to tree position in a stand (Schmid-Haas and Bachofen 1991).

Although we excluded trees with visible symptoms of stem-rot, it may be that the symptoms associated with enhanced stem breakage relate to early phases of infection in the lower stem part, which remained undetected. In spruce trees which were experimentally inoculated by a pathogen, N-concentration in sapwood was increased (Alcubilla et al. 1976). Root rot infection often leads to specific tissue reactions such as development of a barrier zone and has been found to be associated with elevated $\mathrm{K}, \mathrm{Ca}$ and $\mathrm{Mg}$-concentrations in sapwood (Tomiczek 1990). In sapwood of our control trees, $\mathrm{K}, \mathrm{Ca}$ and $\mathrm{Mg}$ concentrations are, however, at the usual level, or even lower (Table 1), making undetected root rot infections at least unlikely. Furthermore, there may be genetic differences among trees in their response to $\mathrm{N}$-addition (Spinnler et al. 2003). Trees with higher N-supply-for whatever reason-may also develop lusher crowns, which in turn may cause stems to become more sensitive to extreme wind velocities.

All in all it appears that vigorous tree growth during the last decade increased the risk of stem breakage, whereas based on the wood parameters examined here, uprooting seems to be a random phenomenon, permitting no differentiation from control trees. Evidence from manipulative experiments with spruce saplings suggests that the tree $\mathrm{C}: \mathrm{N}$ balance plays a critical role in wood mechanics (Beismann et al. 2002) and we suspect that increased growth and $\mathrm{N}$-supply did reduce mechanical resistance of broken trees in our Switzerland-wide sample. Of course, such an $\mathrm{N}$-induced reduction of mechanical strength of stem wood is only one facet of tree-associated wind-throw risk compared with other risk factors such as depth and density of rooting, density and/or asymmetry of crowns, canopy surface roughness. The question why an increased N-supply selectively stimulated and affected our broken trees, while other, slower thickening but similarly high individuals at the same site remained unaffected (or were uprooted) awaits further examination.

Acknowledgments We would like to thank Prof. W. Stern, Mineralogisch-Petrographisches Institut der Universität Basel, for spectrometric analysis, Dr. S. Braun and Prof. W. Flückiger, Institut für Angewandte Pflanzenbiologie IAP, Schönenbuch, for nitrogen analyses in sapwood, and Dr. B. Rihm, METEOTEST Bern, for providing atmospheric nitrogen deposition data. We are grateful to O. Bignucolo, V. Chevillat, S. Guillod, D. Häring, A. Ochsner, V. Schäfer, N. Schild, L. Wacker and T. Zumbrunn for extensive field and laboratory assistance. This study was funded by the Bundesamt für Umwelt (formerly BUWAL, now BAFU) Bern, as part of the LOTHAR research program, contract no. 810.3189.016.

\section{References}

Alcubilla M, Aufsess HV, Rehfuess KE (1976) Nitrogen-fertilization experiments in a norway spruce stand (Picea abies Karst) of stagnant growth on devastated marly rendzina-effects on nutrient contents of spruce tissues and height increment. Forstwiss Centralbl 95:306-323

Amarasekara H, Denne MP (2002) Effects of crown size on wood characteristics of Corsican pine in relation to definitions of juvenile wood, crown formed wood and core wood. Forestry 75:51-61

Anonymous (1986) Certified reference material. Certificate of analysis. BCR No 60-62. Community Bureau of reference-BCR, Brussels

Anttonen S, Manninen AM, Saranpää P, Kainulainen P, Linder S, Vapaavuori E (2002) Effects of long-term nutrient optimisation on stem wood chemistry in Picea abies. Trees 16:386-394

Bauer GA, Persson H, Persson T, Mund M, Hein M, Kummetz E, Matteucci G, Oene H van, Scarascia-Mugnozza G, Schulze ED (2000) Linking plant nutrition and ecosystem processes. In: Schulze ED (ed) Carbon and nitrogen cycling in european forest ecostystems. ecological studies, vol 142. Springer, Berlin, pp 63-98

Beismann H, Schweingruber FH, Speck T, Körner Ch (2002) Mechanical properties of spruce and beech wood grown in elevated $\mathrm{CO}_{2}$. Trees 16:511-518

Belsley DA (1990) Conditioning diagnostics: collinearity and weak data in regression. Wiley, New York

Berz G (2003) Sturmrisiko und Klimaänderung: Sind unsere Vorsorgestrategien noch richtig? GAIA 12:252-254

Bräker OU (1981) Der Alterstrend bei Jahrringdichten und Jahrringbreiten von Nadelhölzern und sein Ausgleich. Mitt forstl Bundesversuchsanst 142:75-101

Braun S, Flückiger W, Leonardi S, Graber W, Joss U, Nater W, Siegwolf R (1996) Belastungen des Gebirgswaldes. Ansätze 
einer Risikobeurteilung. Umweltmaterialien Nr. 59 Wald/Luft. Bundesamt für Umwelt, Wald und Landschaft BUWAL, Bern

Braun S, Schindler C, Volz R, Flückiger W (2003) Forest damages by the storm "Lothar" in permanent observation plots in Switzerland: the significance of soil acidification and nitrogen deposition. Water Air Soil Pollut 142:327-340

Bresh DN, Bisping M, Lemcke J (2000) Storm over Europe-an understimated risk. Swiss Reinsurance Company, Zürich

Chatterjee S, Hadi AS, Price B (2000) Regression analysis by example. Wiley, New York

Dunham RA, Cameron AD (2000) Crown, stem and wood properties of wind-damaged and undamaged Sitka spruce. For Ecol Manage 135:73-81

Dünisch O, Bauch J, Puls J, Müller M (1996) Biological and chemical wood properties of long-term polluted spruce (Picea abies [L.] Karst.) at high-altitude stands of the Erzgebirge. Holzforschung 50:497-506

Dvorak L, Bachmann P, Mandallaz D (2001) Sturmschäden in ungleichförmigen Beständen. Schweiz Z Forstwes 151:445-452

Feger KH, Raspe S, Schmid M, Zöttl HW (1991) Verteilung der Elementvorräte in einem schlechtwüchsigen 100jährigen Fichtenbestand auf Buntsandstein. Forstwiss Centralbl 110:248-262

Hättenschwiler S, Schweingruber FH, Körner C (1996) Treering responses to elevated $\mathrm{CO}_{2}$ and increased $\mathrm{N}$ deposition in Picea abies. Plant Cell Environ 19:1369-1378

Herman M, Dutilleul P, Avella-Shaw T (1998) Growth rate effects on temporal trajectories of ring width, wood density, and mean tracheid length in Norway spruce (Picea abies (L.) Karst.). Wood Fiber Sci 30:6-17

Hoch G, Popp M, Körner Ch (2002) Altitudinal increase of mobile carbon pools in Pinus cembra suggests sink limitation of growth at the Swiss treeline. Oikos 98:361-374

Hohenadl R, Alcubilla M, Rehfuess KE (1978) Stem phloem analysis as diagnostic tool to evaluate the nutritional-status of conifers. Z Pflanz Bodenkunde 141:687-704

Holbrook MN, Putz FE (1989) Influence of neighbors on tree form: Effects of lateral shade and prevention of sway on the allometry of Liquidambar styraciflua (sweet gum). Am J Bot 76:1740-1749

Joos K (1997) Ionengehalt und elektrische Leitfähigkeit im Splintholz, Zuwachsleistung und Nadelverlust bei Fichte unter Berücksichtigung ihrer Nährstoffversorgung. Wissenschaftliche Berichte der Professur Holzwissenschaften 1/1997

Kenk G, Fischer H (1988) Evidence from nitrogen fertilisation in the forests of Germany. Environ Pollut 5:199-218

Körner Ch (2003) Carbon limitation in trees. J Ecol 91:4-17

Körner Ch, Miglietta F (1994) Long term effects of naturally elevated $\mathrm{CO}_{2}$ on Mediterranean grassland and forest trees. Oecologia 99:343-351

Mäkinen H, Saranpää P, Linder S (2002) Wood-density variation of Norway spruce in relation to nutrient optimization and fibre dimensions. Can J For Res 32:185-194

McCarthy DP, Luckman BH, Kelly PE (1991) Sampling height-age errors correction for spruce seedlings in glacial forefields, Canadian Cordillera. Arct Alp Res 23:451-455

McLauchlan KK, Craine JM, Oswald WW, Leavitt PR, Likens GE (2007) Changes in nitrogen cycling during the past century in a northern hardwood forest. PNAS 104:7466-7470

Mason WL (2002) Are irregular stands more windfirm? Forestry $75: 347-355$

Moore JR (2000) Differences in maximum resistive bending moments of Pinus radiata trees grown on a range of soil types. For Ecol Manage 135:63-71

Nadelhoffer KJ, Emmett BA, Gundersen P, Kjonaas OJ, Koopmans CJ, Schleppi P, Tietema A, Wright RF (1999) Nitrogen deposition makes a minor contribution to carbon sequestration in temperate forests. Nature 398:145-148

Niklas KJ (1992) Plant biomechanics: an engineering approach to plant form and function. The University of Chicago Press, Chicago

Niklas KJ (1994) The allometry of safety-factors for plant height (in structure and development). Am J Bot 81:345-351

Norton DA, Palmer JG, Ogden J (1987) Dendroecological studies in New Zealand. I. An evaluation of tree ages estimates based on increment cores. NZ J Bot 23:373-383

OcCC (2003) Extremereignisse und Klimaänderung. Beratendes Organ für Fragen der Klimaänderung OcCC, Bern

Petty JA, Swain C (1985) Factors influencing stem breakage of conifers in high winds. Forestry 58:75-84

Puhe J (2003) Growth development of the root system of Norway spruce (Picea abies) in forest stands-a review. For Ecol Manage 175:253-273

Putz FE, Coley PD, Lu K, Montalvo A, Aielleo A (1983) Uprooting and snapping of trees: structural determinants and ecological consequences. Can J Forest Res 13:1011-1020

Rihm B (1996) Critical loads of Nitrogen and their Exceedances. Environmental series No. 275. Federal Office of Environment, Forest and Landscape (FOEFL)

Rinn F (1996) TSAP Reference Manual version 3.0. Heidelberg

Schiesser HH, Pfister C, Bader J (1997) Winter storms in Switzerland north of the Alps 1864/1865-1993/1994. Theor Appl Climatol 58:1-19

Schmid-Haas P, Bachofen H (1991) Die Sturmgefährdung von Einzelbäumen und Beständen. Schweiz Z Forstwes 142:477-504

Seeling U (1999) Einfluss von Richtgewebe ("Druckholz") auf Festigkeit und Elastizität des Fichtenholzes. Holz Roh Werkst 57:81-91

Spiecker H, Mielikäinen K, Köhl M, Skovsgaard J (Eds) (1996) Growth trends in European forests. European Forest Institute Research report No.5. Springer, Heidelberg

Spinnler D, Egli P, Körner C (2003) Provenance effects and allometry in beech and spruce under elevated $\mathrm{CO}_{2}$ and nitrogen on two different forest soils. Basic Appl Ecol 4:467-478

SPSS Inc. (2000) SPSS for Windows 10 Software package Chicago

Stockfors J, Linder S (1998) The effect of nitrogen on the seasonal course of growth and maintenance respiration in stems of Norway spruce trees. Tree Physiol 18:155-166

Tomiczek C (1990) Forstpathologische Erhebungen im Gebiet der Glein (III). Wurzel- und Stammfäulen-eine mögliche Ursache von Nährelementmangel in Fichtennadeln. Mitt Forstl Bundeversuchsanst Wien 63:71-97

Walinga I (ed) (1995) Plant Analysis Manual. Kluwer, Dordrecht

Wang Y, Titus SJ, LeMay VM (1998) Relationship between tree slenderness coefficients and tree or stand characteristics for major species in boreal mixedwood forests. Can J For Res 28:1171-1183

Wimmer R (1995) Intra-annual cellular characteristics and their implications for modeling softwood density. Wood Fiber Sci 27:413-420

WSL/BUWAL (Ed) (1999) Lothar. Der Orkan 1999. Ereignisanalyse. Eidg. Forschungsanstalt WSL und Bundesamt für Umwelt, Wald und Landschaft BUWAL, Birmensdorf, Bern

Young TP, Perkocha V (1994) Treefalls, crown asymmetry, and buttresses. J Ecol 82:319-324

Zobel BJ, Buijtenen JP van (1989) Wood variation: its causes and control. Springer, Berlin

Zöttl HW (1990) Ernährung und Düngung der Fichte. Forstwiss Centralbl 109:130-137 